\title{
Fragments in the Archive: The Khmer Rouge Years ${ }^{1}$
}

\author{
Annette Hamilton
}

Cambodia's cinema history is strange and surprising. Popular films from France and the United States circulated through the Kingdom during the French colonial period. The 1950s and 60s saw extensive local production with the enthusiastic support of King Norodom Sihanouk, himself a passionate filmmaker, but the Khmer Rouge regime (1975-1979) destroyed most of the existing material, including hundreds of feature films, raw footage and countless other ephemeral documents. In 2006, after representations by film-maker Rithy Panh and others, the Bophana Audio-Visual Research Centre was established in Phnom Penh to comb the world for every fragment of film and audio material relating to Cambodia's history in order to reproduce it in an accessible digitized form. The archival preservation and duplication has continued apace. However the ethical use of these materials presents challenges. Contemporary documentary makers and digital enthusiasts frequently use fragmentary footage to support their political or historical interpretations without attribution or context. This paper discusses a propaganda film featuring the former King Norodom Sihanouk and his wife Monique shot in1973 in collaboration with the Communist Chinese, the North Vietnamese and the Khmer Rouge. Short scenes and extracts from this film circulate online and appear in many documentaries. The "archive effect" of this footage raises questions about the source and circulation of archival images with significant historical and political consequences.

Keywords: Archives; the "archive effect"; documentary; Cambodia; Khmer Rouge; Bophana Centre; Sihanouk

Archives have become an important resource for building contemporary understandings of history. Rapidly developing interest in theories about the archive produce research largely concerned with the techno-philosophy of digital memory. Edited works such as The Archive in Motion:New Conceptions of the Archive in Contemporary Thought and Media Practices (Røssaak, 2010) trace emerging relations between the archive, art, philosophy, and new media practices. Wolfgang Ernst's (2012) work in Media Archaeology offers a post-humanist analytical framework. This paper does not propose to enter the "battleground of epistemology" in contemporary scholarship on nonfiction film; instead, it addresses the subject from the perspective of Media Anthropology, concerned with the intersection between communicative practices and events in specific social and cultural contexts.

Documentary-style cinema proliferates both formally and informally. Private individuals can make their own documentaries by plundering resources from thousands of sites and distributing them on platforms like YouTube. Commercial documentaries circulate on independent networks 
and form an important element of popular education and entertainment. In both cases projects may reproduce fragmentary material from diverse archival sources.

The use of archival images in documentary cinema emerges as a key issue in history and memory scholarship. Debate about the ethics and aesthetics of images with regard to genocide and the Holocaust has proliferated (Saxton, 2008; Bangert, Gordon, and Saxton, 2013). These concerns have extended into the wider field of visual studies of trauma cultures (Pollock, 2013; Frosh, 2018). In the first six months of 2018, twenty four peer-reviewed articles on this topic appeared in academic journals (at my own count).

The ethics of reproduction of images of extremity in still photographs and moving film remains a central concern. However it is not only disturbing and horrific images such as those of the Nazi death camps which give us pause. Historical and political interpretations are deeply influenced by the way archival materials are used. Documentarians make free use of whatever archival materials they can obtain to make more compelling their particular narrative interpretations (Baron, 2014). Programmers, broadcasters and viewers respond to archival fragments as if they offer a guarantee of truth and objectivity.

Reece Auguiste (2015) draws attention to endemic problems in film practice as archives become integral to narrative structure and modes of visual address in most documentary styles:

In the conventional documentary form rarely [are] the epistemological and ontological operations of the archive as a structuring presence taken into account; and even more rarely [do] the pedagogical implications of the archive warrant interrogation in terms of the historical authenticity that it purports to articulate. (p. 12)

Jaimie Baron's (2014) work on "the archive effect" highlights issues around archival preservation, found footage, and the audio-visual experience of history. It is especially useful for exploring the spectatorial experience of archival material in appropriation film. She describes how the spectator's engagement with archival material operates during different filmic experiences. The use of appropriated audiovisual documents produces a particular effect on the viewer, endowing the work with evidentiary authority.

Yael Hersonski's work A Film Unfinished (2010) has been a key reference in debates over the ethics of the archive. The body of raw film-material known as Das Ghetto [The Ghetto], found hidden in a forest bunker after the end of the war and relocated to the Filmmuseum Potsdam, Germany, 
became a primary resource for documentary film-makers concerned with the Holocaust in Poland. Film-makers used random extracts from the footage located at the Filmmuseum without attribution. It was only after the discovery of two additional reels of film in 1998 that the reality became clear: The material long-accepted as authentic depiction had in fact been constructed using numerous faked scenes and staged scenarios. Böser's (2012) detailed interrogation offers an important case study of the vulnerability of archival film to machinations of power, historical falsification, and simple misunderstanding. According to Böser, "the process of audio-visual quotation raises questions about the historicity and origin of the archival footage, about what it was once meant to mean" (p. 38).

Böser's (2012) discussion helps clarify the fluctuating meaning of an important film shot in Cambodia in 1973 parts of which are frequently plundered for inclusion in other films or reportage. Although no title is attached, nor is any director named, it is usually refereed to as Trip to the Liberated Zone..$^{2}$ It consists of an assemblage of largely unedited footage in temporal sequence, which follows the journey of deposed monarch Norodom Sihanouk and his wife Monique down the Ho Chih Minh trail from Vietnam into the heartland of Khmer Rouge territory. This film is widely cited by Khmer people (and others) as proof that Sihanouk did indeed support the Khmer Rouge and to that extent was personally responsible for their final takeover of Cambodia and the tragic genocidal events which followed. Fragments of the footage, and an associated body of stills and photographs, have had wide circulation, turning up not only in film documentaries but in many ephemeral reports and digital sources.

Cambodia under the Khmer Rouge (1975-79) is often referred to as a case of "genocide" thus associating it with the actions of the Nazi regime in World War Two (Schabas, 2001). Extensive film and photographic records were made during the Nazi era, some officially and others by participants including officers. However most of this material was destroyed at the end of the war, either deliberately or as a result of the fire-bombings. Thus there are comparatively few surviving visual (and aural) records of the Nazi atrocities. Many that did survive were used in the Nuremberg trials and are discussed in many sources, for example the United States Holocaust Museum online sites. (https://www.ushmm.org "Combating Holocaust denial: evidence of the Holocaust presented at Nuremberg").

By contrast, very little film or photographic material was shot during the Khmer Rouge (KR) era with the exception of photographic records of the prisoners entering prison. These have become iconic and can be seen in almost every publication and documentary on Cambodia as well as online (Chandler, 2000; Benzaquen, 2014; Caswell, 2014). In addition, a small 
quantity of film footage was shot during the KR years and images from this material is now also essential in the construction of most documentary cinema on Cambodian history. The main source of these archival images was discovered in France. Many Khmer believe that more extensive images especially those related to violence and extremity do exist but have been removed or hidden from public access (e.g., Phay Soko, 2015).

\section{Bophana Audio-Visual Resource Centre}

Although the Khmer Rouge deliberately set out to destroy all kinds of records of the pre-revolutionary era-their aim was to begin Cambodia as if there had been no prior history, from Year Zero (see Ponchaud, 1978)— there was in fact a certain amount of early material to be recovered. The Bophana Audio-Visual Resource Centre was established by renowned film-makers Rithy Panh and Ieu Pannakar in 2006. The Centre archives in two to three languages-Khmer, English, and French - a rich repository of rare materials, including: film, tape, and photographs laboriously collected from the scattered remnants of the nation's audio-visual history. Rithy Panh's leadership and inspiration have been central to the establishment and maintenance of the Bophana Centre. His pre-eminent role in the recuperation of memory and history through intimate documentary cinema has made possible this extraordinary achievement (Hamilton, 2013a). Recently, Bophana has become an incubator for young Khmer film-makers tasked with the preservation of memory, culture, and history (Hamilton, 2013b).

The archive serves many purposes, not least the education of contemporary Khmer. Often on the long, hot afternoons students view computer screens on which all kinds of materials can be called up. Old movies, recent documentaries, and commentaries cover many aspects of Cambodia's visual history.

Although rarely seen or discussed, over one hundred items in the Bophana collection were shot during the Khmer Rouge years. At various times in 2011 and 2012, I spent many hours exploring this body of material. Some short films were shot as propaganda, recording state visits and cultural performances. Others consist of raw black and white footage without commentary or subtitles showing activities such as salt-making, dambuilding, and manufacturing work. In referring to these as "fragments," I make no assumptions about the original purposes of these records.

The French National Audio-Visual Institute holds copies of some of this material, which can be viewed online. They include Military Rally in Phnom Penh (1975), Military Meeting of the Revolutionary Army (1976), Communist Party of Kampuchea Congress in September (1977). 
Archival staff members at the Bophana Centre agree that most, if not all, of this footage was shot by Chinese cameramen using Chinese equipment. (Mr. Sopheap Chea and other staff members discussed this with me on several occasions during my research in the archives in 201213). Khmer film-makers and photographers would already have fled or been executed at the time these films were made. No other outsidersjournalists, documentarians, photographers-were permitted to make records or reports, until in 1978 a delegation from Yugoslavia was invited to make a film showing the successes of the regime. Nikolai Vitorovic was given assistance and support to travel to various parts of the countryside in order to demonstrate that all was well in Cambodia despite horror stories beginning to circulate outside its borders. He shot the film in various parts of the country on what seems to have been a formal visit with a number of Yugoslav dignitaries. There is no complete version available of the original film titled Kampucija 1978. Some of the footage was repackaged for French television with a commentary by a French journalist under the title Le Cambodge 1978. Another French television program was made in 2011, under the title Mystères d'archives: 1978, les images retrouvées des Khmers Rouges re-utilising material from Vitorovic's film. These are available at the Bophana Centre and also online through INA.fr, the first with the subtitle "Question de temps 19/04/1978".

Parts of the film depict Khmer "slaves" building dams and harvesting salt. When the film was inadvertently shown at a Government function in Phnom Penh, Foreign Minister Ieng Sary personally ordered that the projectionist be executed (Picq, 1989).

So, although limited, there is some film material available with which contemporary film-makers and others can work when depicting elements of Cambodian politics and history during the KR years. However simply viewing the material for its "archival effect" does not imply any understanding of the context. For instance, the frequently repeated footage of black-clad, barefoot women carrying baskets of rock and mud up and down dam-construction sites does not allow the viewer to understand who these people were or why they were doing this. Contemporary film-makers use fragmentary footage and focus on iconic images to support their own historical interpretations. Few Khmer and fewer foreign scholars are familiar enough to query or challenge the appropriate use of these interpretations. The limitations on the archival material do not arise simply because material was lost or destroyed. In fact the Khmer Rouge did not endorse the use of film or of any other form of recording for that matter. It was part of their ideology that the genuine Khmer people should live entirely without the trappings of modernity, as much like ancient times as possible (Boradem, 2013; Locard, 2005). Film 
could be used to show things to outsiders, but it had little purpose in the new post-revolutionary world. This was very different to the situation in other socialist/Communist regimes.

In most socialist regimes in Asia-China, Vietnam, and North Koreafilm was a popular medium and a means of enthusing the public with revolutionary goals. News films or propaganda documentaries and narrative feature-films became the public entertainment form of choice (Hoffman, 1997; Papezian, 2014; Pang, 2013). In Cambodia the public, as such, no longer existed. Leadership, senior cadres, and necessary workers were based in Phnom Penh, a city emptied of all other population. Previous town and city dwellers were forced into labour camps, some located near established agricultural peasant villages, and others on uncleared land (Chandler, 1993; Kiernan, 2008). Here, the Khmer Rouge theorists announced they would create an enlarged agricultural sector using nothing but the labourers' bare hands. There was neither the infrastructure nor ideological need for film. The whole of Cambodia was like one giant prison camp, and radio broadcasting was its chosen means of communication and live cultural performance the main means of entertainment (Ponchaud, 1978; Tyner, Rhodes and Kimsroy, 2016).

\section{Trip to the Liberated Zone (1973)}

While the Khmer Rouge did not support film as a means of popular communication, the film referred to above may have been a remarkable exception. Shot in 1973 with the assistance of the North Vietnamese and the Chinese the film is often claimed to demonstrate that Norodom Sihanouk was a keen adherent of the Khmer Rouge. It was made while Khmer Rouge support grew in the Cambodian countryside, before the takeover of 1975 . It shows a secret visit by the ex-King and his wife Monique to the Khmer Rouge base near Angkor Wat in Western Cambodia

Images from this film began to circulate long before the film itself was ever screened. One photographic still $(31 \times 21 \mathrm{cms})$ is in the Asian Studies collection at Monash University in Melbourne, Victoria, listed as "Le Chef d'État visite une pagoda contemporaine". The collection title is Trip to the liberated zone of Cambodia March/April 1973. The photograph shows the King wearing black Khmer Rouge style pyjamas standing alone in front of a pagoda at Angkor Wat (Short, 2006). Had there been nothing but the stills, it might well have been an elaborate hoax. The US-backed military regime denied the possibility of a secret journey into the countryside. It was certainly a "real" film of a "real" visit. However it offers proof neither of the King's intentions and feelings, nor his genuine support of Pol Pot and cohorts. The King and his family members were held under duress in 
Beijing while the Khmer Rouge leadership courted China and North Korea (Short, 2006). Nevertheless Sihanouk went along with it. But the context in which the film was made does not allow for simplistic assumptions about its effects any more than the faked scenarios of the Warsaw Ghetto can be taken as historical "evidence."

As is well-known, Sihanouk was a passionate film-maker himself although his films are usually regarded as a peculiar personal indulgence or a form of derangement (cf. Osborne, 1994). Having viewed all of his films, including unfinished pieces shot in North Korea while he was in exile there, I do not agree. While his films are hardly professional in quality, the intention behind them was clear. Sihanouk believed he was, as monarch, the embodiment of Khmer history and culture. By making films about Khmer life, starring himself and his family, he was creating a world which made sense to Khmer people, attracted by the glamour and sparkle as well as tragedy and drama of Khmer life, both high and low, on screen. Sihanouk's films were among many made in the golden era of the 1960s and were a reflection of popular taste in the new era of mass communication.

After reading boxes of interviews, opinion pieces and statements he gave over many years (in the Sihanouk Archives at Monash University in Melbourne), I also argue that Sihanouk cannot be understood through conventional Western concepts such as "Left," "Right," Communist or anti-Communist. His primary interest was in maintaining Cambodian independence and neutrality. As Head of State in the 1960s, he had been violently opposed to the rising ultra-Leftist political movement, with its mysterious leadership and diffuse structure. His secret police identified, jailed, and executed many Leftists who were local supporters of the emerging Pol Pot faction. Though the US supported his intolerance towards the Left, his views changed after the US conducted illegal and unacknowledged bombing raids on Cambodian soil (Sihanouk, 1973; Jeldres, 2005).

The first attempted coup against Sihanouk-the topic of one of his most interesting films, Shadow over Angkor (Sihanouk, 1967) - turned him decisively against the US, prompted him to reject US aid altogether, and aligned Cambodia with other socialist regimes like China and North Korea. The loss of US financial support for the Cambodian army was significant motivation for Prime Minister Lon Nol, Prince Sirik Matak, and other conspirators to attempt a second coup in 1970, which successfully overthrew him (Chandler, 1993; Osborne, 1973).

In exile in China and North Korea Sihanouk was horrified at US policies towards Cambodia (Osborne 1994). He was subjected to intense pressure from his hosts (Shawcross 1991; Cioreiari 2014). His position on the Khmer 
Rouge changed; in 1973 he decided that the Khmer Rouge was better than the alternative:

I sincerely believed that the advent in our country of a Chinese form of communism-pure, hard, honest and for the people-was to be preferred from all standpoints to the regime of Lon Nol and Sirik Matak which was totally incompetent and unjust. (Schier \& Schier-Oum, 1980, p. 5)

Sihanouk had always extolled the benefits of a benevolent form of absolute monarchy (Yong, 2013). While this might seem utterly bizarre in the context of the enforced Stalinism being pursued by the Khmer Rouge, it is not inconceivable that Sihanouk could somehow imagine these could be compatible. When reality intruded, it was too late.

Silhanouk was pressured to publicly support the Khmer Rouge and convince his people to do the same. Both the Chinese Communists and Sihanouk himself believed in the power of cinema while his host in North Korea, Kim Jong Il, had written his treatise "Theory of Cinematic Art" (part of which was first published in English as The Cinema and Directing in 1987). It is easy to see how Sihanouk may have been persuaded that undertaking this journey secretly to the heart of Khmer Rouge power, to the national symbolic sacred site of Angkor Wat, would offer a spectacular method of support and lead to the restoration of his influence with his people, who under the Khmer Rouge would overthrow Lon Nol and expel the Americans.

Whether or not Pol Pot and his associates endorsed this vision, it was obvious that Silhanouk's visit would gain widespread support for the KR among a populace which revered the monarchy. Sihanouk and his wife Monique travelled through the Vietnamese jungle and across the border into Laos. At the beginning they wore Viet Cong uniforms but by the end they changed into black KR uniforms-caps and checkered scarves-meeting with the high KR leadership near Angkor Wat.

It was an extraordinary journey. They travelled down the Ho Chi Minh Trail in a cavalcade of Russian-made jeeps with an escort of more than a hundred Vietnamese guards, drivers, cooks, servants, and a medical team, accommodated each night in a guest cottage with running water and plumbing where they were served fresh baguettes for breakfast. From the transit station on the Laotian border where the Vietnamese left them, they spent the next six days being driven at night by KR functionaries to their final destination at Mount Kulen northeast of Siem Reap. Most of the Khmer Rouge leadership were there to honour them, although Pol Pot was at that time still concealing his identity. He was using Pol Pot as his nom 
de guerre rather than his birth name, Saloth Sar, but he was already known as Brother Number One (Short, 2006). The King and Monique visited the temples of Bantei Srey and posed against the 13th century friezes depicting Angkorian overseers and slaves, as if to assert the liberating power of the $\mathrm{KR}$ regime. In several scenes, they are shown laughing, embracing, sharing food and drink on a high platform with the KR leadership, and then walking through the ancient ruins of Angkor side-by-side. (These descriptions are based on my own viewing and analysis of the film at the Bophana Archives in Phnom Penh).

The film is in quite good condition, and allows a clear enough view of several key events: meetings with $K R$ leaders, speeches in a jungle hideout, greetings by KR jungle-based troops along the line, and long visits to Angkor Wat. Segments of the film were uploaded on Youtube from a source other than the copy available from the Bophana archives. Though the material shows the same events, the poor quality makes it difficult to identify individuals unless one is familiar with them. This version of the film was identified as the part of the National Archives of the National Security Council and the CIA, and was copied from a DVD by "IASL Scanner Thomas Gideon" (1973).

\section{A Fragmentary Itinerary}

Were the rural peasantry to be convinced that Sihanouk, whom they revered, supported the Khmer Rouge and wanted them to do the same? How would they have seen these films? Were they screened around the country without the Lon Nol agents, or the CIA, knowing about it? Did the film play a part in making those already living in the Khmer Rouge liberated zones to become even more willing to support the Khmer Rouge. (Many Khmer I have spoken to state that over 5,000 fighters joining the KR after the film was made, but I have so far found no published or official reference to this).

Even more puzzling is the provenance of the film. Where did it come from, and where was it preserved? While Bophana records suggest that the original footage was held by the Department of Cinema and Culture in Phnom Penh in the 1990s, I have been unable to find any records to explain its survival and its preservation. Visits to the National Archives, which have very limited film holdings, did not indicate any trace of the original footage. How did the CIA or National Security Council obtain the Khmer Rouge/ Chinese film footage? Perhaps from China?

Without sound, context, or commentary, the film seems to indicate total complicity between Sihanouk and the Khmer Rouge leadership. Most viewers today do not have any other context or detailed historical knowledge. Eighty years later, Cambodians are likely to take it at face value. 
A critical analysis of the film may conclude that the apparent bonhomie and enthusiasm displayed by the King may be faked, staged, and artificially created. In many scenes Monique looks far less entranced; she looks grimfaced at times. Factors pushing Sihanouk into this performance were complex and varied, but the contemporary viewer has no access to this information. Worse still, viewing chosen fragments or photographic stills inserted into other recently made films suggests there can be no doubt about the extent to which Sihanouk and the Pol Pot leadership were allied.

Documentaries use images to authenticate a viewpoint constructed by the film itself. The "truth" value of archival images can be manipulated depending on the context in which they are used. What are we to think today about the rise of the Khmer Rouge? Should Sihanouk be condemned for his complicity? This position is now widely invoked. Was Sihanouk manipulated and seduced by promises of national independence and a continuing role in a Khmer Rouge regime?

Was he deluded, or did he sincerely believe the Khmer Rouge would be able to expel the Americans and restore Cambodia's independence? Did he have any idea of what the Khmer Rouge ideology and intentions really were? The use of random film fragments designed to consolidate a particular viewpoint does not allow for any such subtle speculations to arise.

\section{Copyright and Archives}

Documentary film-makers need and expect to use archival film as guarantee of objectivity and truth. The "archival effect" relies on the appearance of authentic film material from the time and place in question. The question of copyright ownership over archival material relating to film and images of past historical events is vexed. Relatively simple solutions-such as the doctrine of Fair Use-are scarcely relevant for current dilemmas. Increasingly widespread use of found film, unattributed film, home movies, and discarded footage raises privacy and confidentiality issues (Rao, 2010). Archival services have been professionalised, although very diverse attitudes towards distribution and management of digital images remain (Gracy, 2013).

The incorporation of early film materials into new forms for recirculation proceeds apace. Projects promoting the use of digitised clips from silent films have led to new experiments in crowd-curated remixes. Digitisation, open access, and appropriation lead to new and controversial historiographic approaches and curatorial strategies (Ingravalle, 2015).

On digitised terrain, issues around reality and representation have lost traction in practice as much as in theory; archives have become sources of display and fields of cultural enjoyment. But this is a First World luxury. 
Very different issues are involved in less-developed nations, many still dealing with the aftermath of deeply traumatising histories, the memories of which remain contested and uncertain. As I found when attempting to obtain research copies of some of the films I was studying, Bophana Centre exercises very strict control over any reproduction of the material they hold. They state that copyright is held by the Cambodian Ministry of Culture. Scholars and researchers can view films but are generally unable to obtain copies even for research. How is it then that so many documentary film-makers appear to obtain and use restricted Cambodian archival film material? Frequently they acknowledge the French national archives in the scrolling credits at the end. Did they obtain access to the materials in France? Is this not in contradiction to the wishes of the Cambodian Ministry? Or are special arrangements made?

Is there an ethical obligation to acknowledge the origins and circumstances under which original film material was filmed, and how it was obtained? Can there be a rightful owner? Who should control copyright? A national government? An archive? A television station? Should use and circulation be strictly controlled? Or should footage with historical resonance be readily available to all who wish to interrogate it, use it, or re-present it?

Until 2012, a significant number of extracts from the KR archival material turned up on the Internet including in chat forums to which Cambodia enthusiasts linked free video sources. By 2018 almost all of these have been removed. Who intervened in the circulation of these original images? Why are they now almost inaccessible to the general public?

In raising these questions for the Cambodian archive, the intention is to become more attuned to the ethical issues involved in the reproduction and circulation of images whose provenance is unknown or uncertain and to their use as icons, symbols, and evidence for diverse effects (Struk, 2011). To determine the origins and provenance of many rare and significant archival images requires painstaking research, beyond a reasonable expectation for many filmmakers, but when using currently available and well-documented digital archives a more careful and ethical approach is imperative. 


\section{References}

Auguiste, R. (2015). Archives and invention: the archives structuring presence in documentary film practice. Journal of Media Practice, 16(1), 8-24.

Bangert, A, R., Gordon S. C. \& Saxton L. (Eds). (2013). Holocaustilntersections: Genocide and visual culture at the new millenium. Oxford: Legenda.

Baron, J. (2014). The archive effect: Found footage and the audiovisual experience of history. New York: Routledge.

Benzaquen, S. (2014). Looking at the Tuol Sleng Museum of Genocidal Crimes, Cambodia, on Flickr and YouTube. Media, Culture and Society, 36(6), 790-809.

Boradem, N. (2013) The Khmer Rouge: Ideology, militarism ad the revolution that consumed a generation. Santa Barbara, Ca: Praeger Security International.

Böser, U. (2012). A film unfinished: re-representation of archival footage from the Warsaw Ghetto. Film Criticism, 37, 38-56.

Caswell, M. (2014). Archiving the unspeakable: Silence, memory and the photographic record in Cambodia. Madison, WI:The University of Wisconsin Press.

Chandler, D. P. (1993). The tragedy of Cambodian history: Politics, war and revolution since 1945. New Haven and London:Yale University Press.

Chandler, D. P. (2000). Voices from S-21: Terrror and history in Pol Pot's secret prison. Berkeley: University of California Press.

Cioreiari, J. D. (2014). China and the Pol Pot regime. Cold War History 14, 215-235.

Ernst, W. (2012). Digital memory and the archive. Minneapolis: University of Minnesota Press.

Frosh,P.(2018).The mouse, the screen and the Holocaust witness: Interface aesthetics and moral response. New Media and Society, 20, 551-368.

Gracy, K. F. (2013). Moving image preservation work and the integration of moving image preservation work into cultural institutions. Information and Culture: A Journal of History. 48(3), 368-389.

Hamilton, A. (2013a). Cambodian genocide: ethics and aesthetics in the cinema of Rithy Panh. In Bangert, A. R., Gordon S. C. \&Saxton L. (Eds.), Holocaust intersections (pp. 170-190). Oxford: Legenda.

Hamilton, A. (2013b). Witness and recuperation: Cambodia's new documentary cinema. Concentric: Literary and Cultural Studies, 39(1), 7-30.

Hersonksi, Y. (Director). (2010). A film unfinished. Germany: Oscilloscope Pictures.

Ingravalle, G. (2015). Remixing early cinema: historical explorations of the EYE Film Institute Netherlands. Moving Image: the Journal of the Association of Moving Image Archivists. 15 (2), 82-97.

Jeldres, J. A. (2005). Shadow over Angkor: Memoirs of His Majesty King Norodom Sihanouk of Cambodia. Phnom Penh:Monument Books.

Kiernan, B. (1985). How Pol Pot came to power: A history of communism in Kampuchea, 1930-1975. London: Verso.

Kiernan, B. (2008) (Third Ed.) The Pol Pot regime: race, power and genocide under the Khmer Rouge, 19751979. New Haven:Yale University Press.

Kim Jong II. (1987). The cinema and directing. Pyongyang: Foreign Languages Publishing House. Locard, H. (2005). Pol Pot's Little Red Book: The sayings of Angkar. Chiangmai: Silkworm Books. Meyer, C. (1971). Derrière le sourire Khmer [Behind the Khmer smile]. Paris: Plon. 
Osborne, M. E. (1973). Politics and power in Cambodia: the Sihanouk years. Camberwell, Vic: Longman Australia.

Osborne, M. (1979). Before Kampuchea: Preludes to tragedy. Sydney: George Allen and Unwin.

Osborne, M. (1994). Sihanouk: Prince of light, prince of darkness. Honolulu: University of Hawaii Press.

Pang, L. (2013). Between will and negotiation: Film policy in the first three years of the People's Republic of China. In Rojas, C. (Ed.), The Oxford handbook of Chinese cinemas (pp. 472-489). Oxford: Oxford University Press.

Phay Soko, (2015). Missing images of genocide and creation in Cambodia. Journal of Literature and Trauma Studies 4(1-2), 87-98.

Pollock, G. (2013). Visual politics of psychoanalysis: Art and image in post-traumatic cultures. London: I.B. Taurus.

Picq, L. (1989). Beyond the horizon: Five years with the Khmer Rouge. London:St Martin's Press.

Ponchaud, F. (1978). Cambodia: Year zero. New York: Henry Holt and Co.

Rao, N. (2010). Representation and ethics in moving image archives. The Moving Image: the Journal of the Association of Moving Image Archivists , 10(2), 104-123.

Røssaak, E. (2010). The Archive in motion: New conceptions of the archive in contemporary thought and new media practices. Oslo: Novus Press.

Saxon, L. (2008). Haunted Images: Film, ethics, testimony and the Holocaust. London:Wallflower Press.

Schabas, W. (2001). Cambodia:Was it really genocide? Human Rights Quarterly, 23, 470-477.

Shawcross, W. (1991). Sideshow: Kissinger, Nixon and the destruction of Cambodia. London: Hogarth.

Schier, P. \& Schier-Oum, M. (1980). Prince Sihanouk on Cambodia: Interviews and talks with Prince Norodom Sihanouk, in collaboration with Waldtraut Jarke. Hamburg: Institüt für Asienkunde.

Short, P. (2006). Pol Pot: Anatomy of a nightmare. New York: Henry Holt and Co.

Sihanouk, N. (Director). (1967). Shadow over Angkor. Kingdom of Cambodia. .

Sihanouk, N. (1973). My war with the CIA; the memoirs of Prince Norodom Sihanouk as related to Wilfred Burchett. New York: Pantheon Books.

Sihanouk, N. (1981). Souvenirs doux et amers. Paris: Hachette.

Sihanouk, N. (1973). My war with the C.I.A. Harmondworth: Penguin Books.

Struk, J. (2011). Private pictures: Soldiers' inside view of war. London: I. B. Taurus.

Tyner, J.A., Rhodes, M. \& Kimsroy, S. (2016). Music, nature, power and place: An ecomusicology of Khmer Rouge songs. Geohumanities, 2(2), 395-412.

Turley, W. S. (1986). The second Indo-China war: A short political and military history. Boulder, Co:Westview Press.

Yong, W. (2013) Prince Sihanouk: The model of absolute monarchy in Cambodia, 1953-1970. Senior Thesis, Trinity College, Hartford NJ. 


\section{Notes}

1 The term "Khmer Rouge Years" properly refers to a period from the late 1960s to the end of the 1990s. My research was largely carried out at the Bophana Audio-Visual Research Centre in Phnom Penh, and I made a special study of all the remaining fragments and films from the period 1975 to 1979, when the Khmer Rouge was in control of Cambodia. The present paper is concerned with a film event which took place before the Khmer Rouge had taken Phnom Penh, while former King Norodom Sihanouk and his wife Monique were in exile in China and North Korea. Visit to the Liberated Zone was filmed in 1973 and appears to be the only fragment of archival film associated directly with Pol Pot and the KR made in Cambodia prior to 1975 .

2 The common Khmer term for "a visit" or "a trip" is the same: damnaer kamsan (in English script transliteration). Various notations on or about the film use the Khmer script or the English terms interchangeably.

ANNETTE HAMILTON is Professor Emerita in Arts and Social Sciences at the University of New South Wales in Sydney, Australia. She is a pioneer in the field of Media Anthropology and widely published in Film Studies and Southeast Asian Cultural Studies. Her work on cinema in Thailand and her papers on Australian cinema and national identity are widely referenced. Some of her recent research on Cambodian cinema has been published in several journals and a book is in preparation. 